\title{
ON SITE EDUCATION: A FIRST STEP TO IMPROVED PROTECTION OF ENDANGERED SPACES
}

\author{
PETER JONKER, Extension Division, University of Saskatchewan, Saskatoon,
} Saskatchewan. S7N 0W0

Editor's Note: the following is adapted from the address Peter gave at the Saskatchewan Natural History Society's 43rd Annual General Meeting in October.

As the title suggests, I am going to highlight the importance of learning within wilderness settings. In addition, I will offer a few remarks about one of my programs entitled, "Encounters with Saskatchewan's Endangered Spaces."

In a nutshell, I am going to make two points:

First, that we are challenged to $r$-attach the human psyche to the biosphere which gave us birth and which continues to bear us day by day.

Flowing from this first point is a second - that on-site education (or on-site learning) is a primary vehicle for meeting that challenge.

People need to become re-attached to the biosphere because we live in cultures 'f gross de-tachment. This detachment occurs from the day we draw our first breath of air to the day we expire our last - especially for us citizens of so-called developed, industrialized, technological nacions. Detachment in these developed nations is longstanding - chronic. The result of such chronic detachment is a society that is ecologically dysfunctional. To the extent that our detachment is chronic our ecological dysfunctionalism is also chronic; we are all too familiar with that both locally and globally.

To illustrate detachment from our natural environment, I need provide only a few examples. Not long after birth, the baby bottle separates us from the breast; then our houses, attached garages, our cars insulate us from fluctuations in temperature, wind, moisture; our carefully groomed yards, back alleys, and corner sidewalks comprise an unnatural landscape for our young people; the Walkman offers further detachment; the grocery store separates the vegetables we eat from the soils from which we grow them, the animals we eat from the pastures that nourish them, and the butchers who kill them for us. Our water arrives through faucets and disappears through drains. Our roads and bridges insulate us from a richly varied natural topography.

Televisions, videos, and the National Enquirer have flourished to fill a vast population of eroded psyches with a new artificial reality where stars perform on stages and wildlife happens when you bring over the beer.

Examples such as these are only symptomatic, however. The actual malady lies deeper than that.

In a sense, and I want to believe this can change, western culture has made a science of detachment. In fact, our scientists, and hence our sciences, have for several centuries prided themselves on being "objective," as is the fondly used term which boils down to meaning that they perceive 


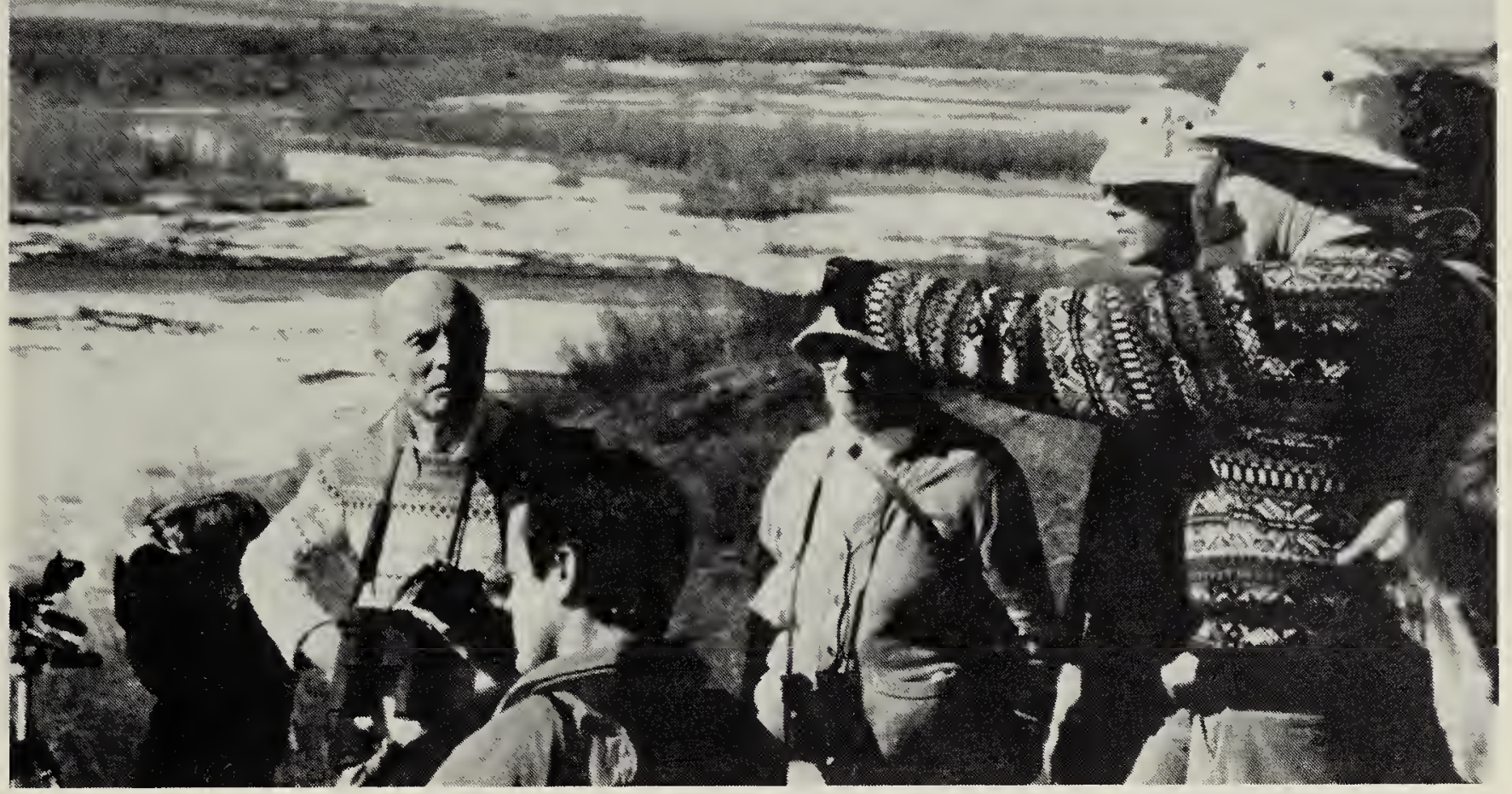

Professor Stan Rowe explains landscape ecology of the South Saskatchewan River Valley near Saskatoon.

P. Jonker

themselves and their disciplines to be apart from and above all those other fields of scholarly study that are too much encumbered by heavy-handed values and philosophies. And, wouldn't you know it, these scientists are perhaps our most venerated social institution.

This is not to implicate science as the only or ultimate driving force behind this mis-direction. The malady lies still deeper.

I suspect our society is ecologically dysfunctional because the majority of its citizens today perceive themselves apart from and above the interaction of forces that characterize the biosphere. I believe that our detachment from the biosphere is ultimately a matter of the human mind.

Martin Heidegger, a venerated German philosopher, has drawn attention to our inclination to engage only in "representational thinking," and to neglect more fundamental soul searching. ${ }^{1}$ You can easily recognize thinking as all the thinking you do of things, objects, ideas which appear to exist apart from you. Another level of thinking, the soul searching which he calls "open thinking," occurs when you ponder your very being. Why do I exist? Why does anything exist? Perhaps it 49(4). December 1991 would be better if we were to attend regularly to both these levels of thinking.

Words, ideas, language are the first technology to enable representational thinking. Perhaps, and ironically as Mark Meisner recently pointed out, the same evolutionary development of language skill that many proudly believe sets us apart from and above all other organisms, may indeed be the opening act of human/environment apartheid. ${ }^{2}$ They are the cells and shackles by which we first imprison and then force the dynamic ecosystem into our human service. They are representational thinking.

So, what should be our best counter response? Our most informed remedy?

Firstly then, we need to be guarded against making the mistake of restricting ecology (or environmentalism, or natural history if you prefer) to the mental realm of scientific concepts. To follow this path would merely support and perpetuate the same representational thinking and associated management posture that needs to take a back seat to genuine reflection on our being.

Having said that, I want to encourage you, and challenge you in tum to en- 


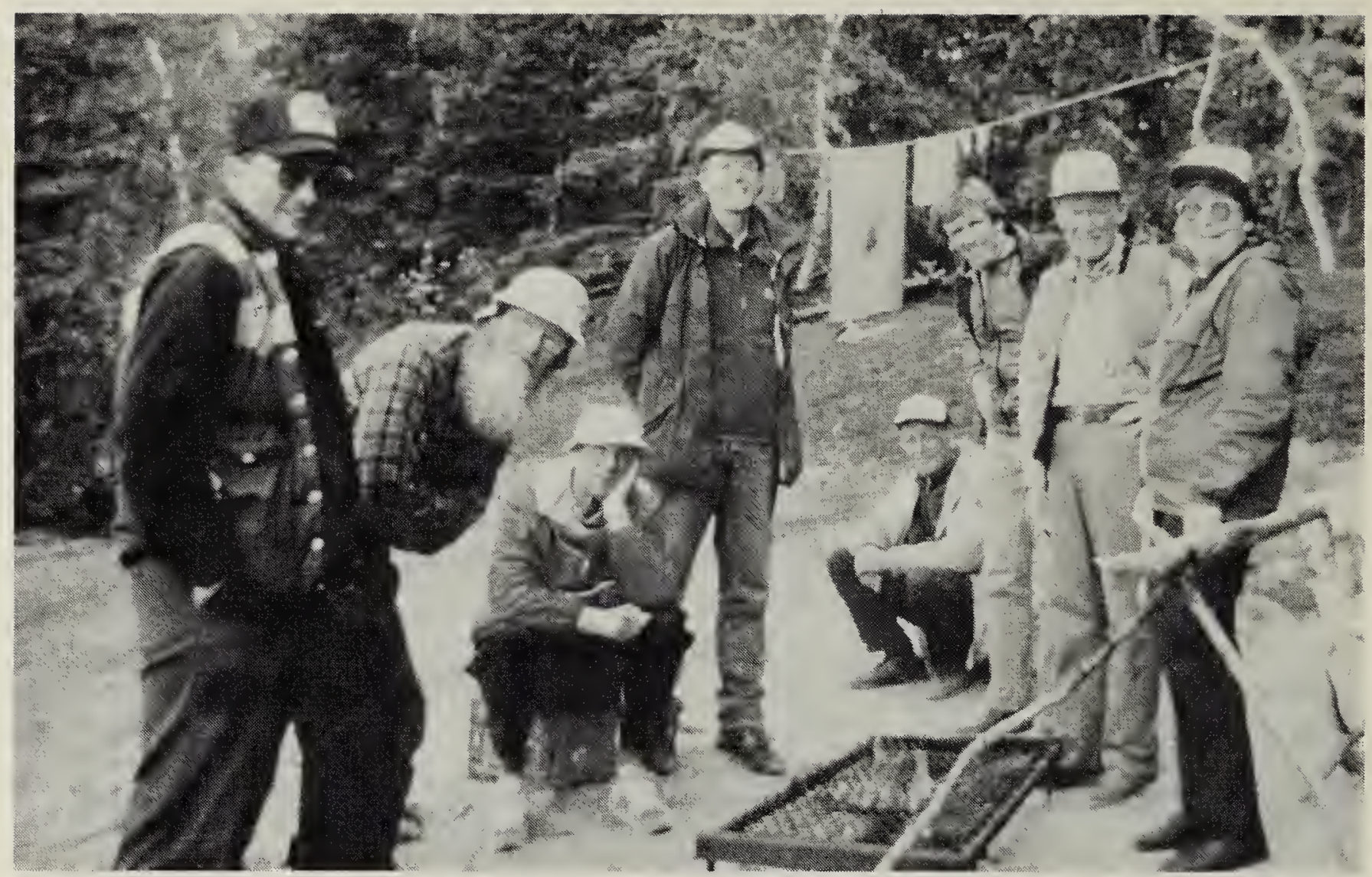

Some members of the group guided through the Athabasca Sand Dunes, June 1991: (l. to r.) Adam Kosawan, Courtenay Milne, John Gerrard, Ken Norman, Cliff Matthews, Peter Jonker, Stan Rowe, Thelma Howard.

courage others within your reach, to continue to discover and learn within wilderness settings. It is exciting to see the lively schedule of outings organized throughout the year by members of the Saskatchewan Natural History Society and its many affiliates. This, I believe, is holistic leaming; the kind that spawns desperately needed respect and humility. I'm not restricting myself to learning bird identification, because I believe that natural history is much larger than that. I find that books and lectures assist me, but no leaming equals that which you feel, and which occurs by being there, sleeping there, walking there. Observing details with your own eyes, smelling changes with your own nose, hearing momings and evenings and midnights with your own ears; with your own fingers touching decaying bark, seeping earth, drying leaves, cooling stone.

This, I believe, is the eco-centric learning that Stan Rowe referred to in an essay entitled "Wilderness As Home Place":

"The only firm foundation for wilderness preservation is psychological and attitudinal. ... Ecocentric education, switching the emphasis away from ourselves, is the key."

In the long haul, the preservation of wilderness depends on attitudes; not management attitudes but attitudes born during those times when you lie awake under a myriad of frosty stars and hear the soft chatter of an invisible slipstream of swans winging southward.

***

I have been trying to take this approach to heart. About a year and a half ago, in my capacity as the Coordinator for Environment Science and Technology programs, I asked a group of environmentalist friends to give me some programming direction. One of the programs I initiated as a result of that consultation is entitled "Encounters with Saskatchewan's Endangered Spaces" and I want to tell you a little bit about it.

The essential ingredient of this program is field study. There are numerous programs available throughout Saskatchewan and certainly throughout western Canada that bring people into remote places. But these are by and large 


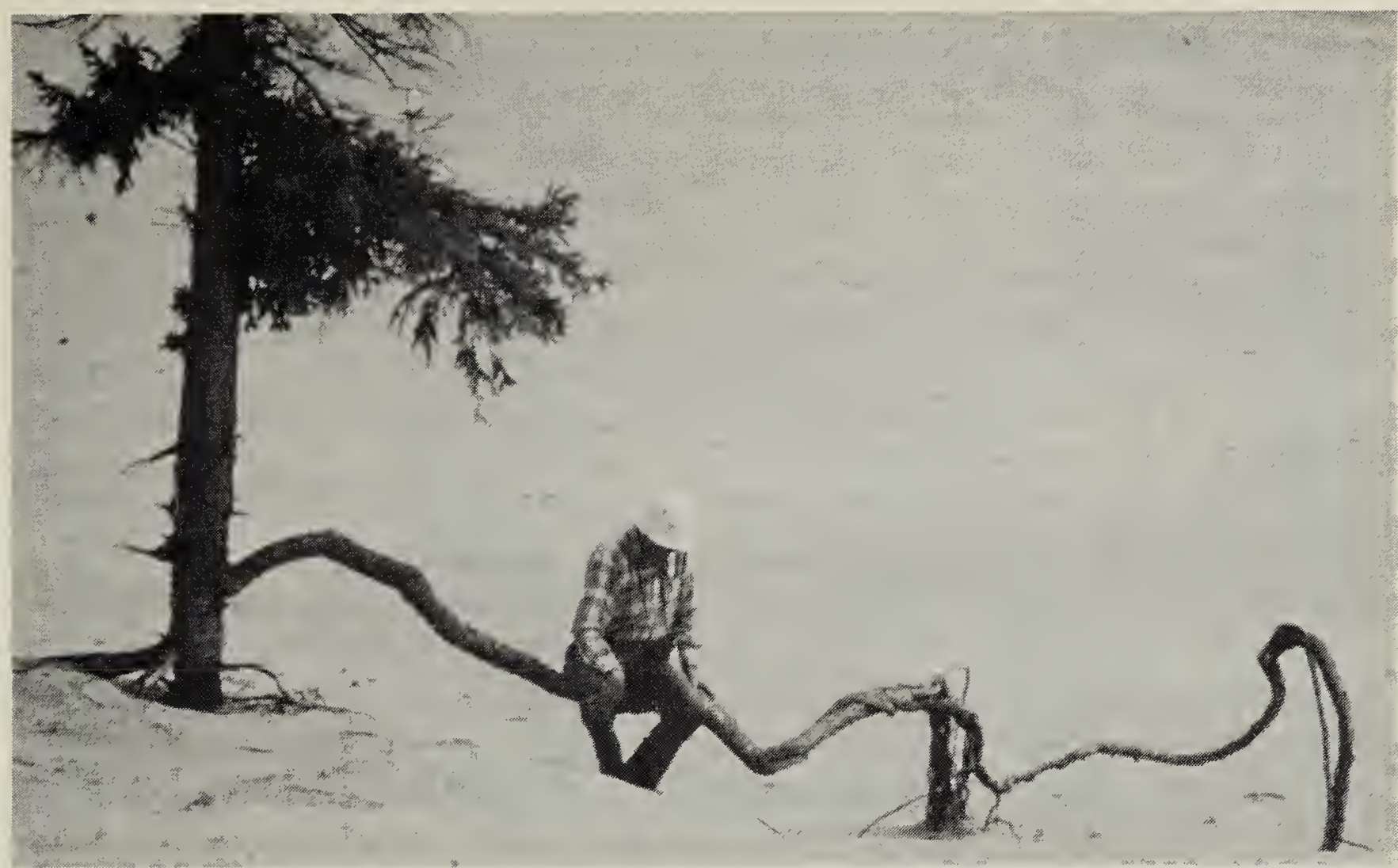

Professor Stan Rowe seated on a wind-exposed lateral root of White Spruce near William River.

P. Jonker

tourism-driven wildemess adventure trips or "eco-tours." These are field visits. The program I seek, and which I will continue to build upon, is one whose primary focus is field eduction, and whose primary target is interested members of the public. Although the program is fledgling, I have tried to improve it each year.

In keeping with this goal of educating, during the first year I organized one full day of lectures, which was followed by a second long day of field study in the Saskatoon area. Thereafter, the program conducted three overnight trips: one to Cypress Hills, one to Grasslands National Park, and a third to the Athabasca Sand Dunes. The first two of these overnight trips were made in cooperation with the Saskatchewan Natural History Society, and were successfully administered by Stan Shadick. Sixty-six people attended the lectures and the Saskatoon area trip, twenty people attended each of the Cypress and Grasslands trips, and eight attended the Athabasca Sand Dunes field study. As result of the first year's series, and with some financial support from the Saskatchewan Natural History Society and the Canadian Parks and Wilderness Society, we are preparing a book entitled, Saskatchewan's Endangered Spaces: An
Introduction. It is expected to be printed by March, and will also form a basic reading text for the program from year to year.

Beginning this year, and during future years, Encounters With Saskatchewan's Endangered Spaces will try each year to focus on and highlight a specific region within the province. This year it will be the Churchill River area, and next year it will be the grasslands. Participants will be introduced to local geology, soils, vegetation, and wildlife - and most importantly, how these interact.

I deeply appreciate the support that you as individuals, and the Saskatchewan Natural History Society, have shown for this program.

I invite anyone who is interested in contributing ideas to this program, or who would like to be on the mailing list for a brochure, to contact me at the University of Saskatchewan Extension Division.

1. HEIDEGGER, MARTIN. 1977. Translated by $\mathrm{W}$. Lovitt. The question conceming technology and other essays. Harper and Row Publishers, New York.

2. MEISNER, MARK. 1991. Words and worlds: language and the perceived separation of humans from nature. Undercurrents 3:3-11. 